\title{
Cultural Conflicts in Chitra Banerjee's Arranged Marriage
}

\author{
C.G. Karthikadevi, R. Kannan
}

\begin{abstract}
Literally 'Diaspora' means 'to scatter' or dispersion, It refers to the loss of homeland, a shift of population from one locale to another. The expatriate writer undergoes the pain of homelessness, alienation and a sense of belongingness. The old memories keep on hovering in the mind of expatriate writers. The new land and unfriendly neighbourhood lead to the feeling of frustration and depression. There are so many Indian English writers can be recognized under the umbrella of diaspora: Salman Rushdie, Anita Desai, V.S.Naipaul, Rohinton Mistry, HanifKureishi, Bharati Mukherjee, JhumpaLahiri, Chitra Banerjee Divakaruni etc. Chitra Banerjee Divakaruni is an Indian born American settled author. Her works are mostly set in India and the United States. She has also focussed on the experiences of South Asian immigrants. Her debut short story collection Arranged Marriage won an American Book Award in 1995. The paper highlights how the Indian born women encounter the difficulties and knots in their new lives in America through the short story collection Arranged Marriage.
\end{abstract}

Key Words: Diaspora, Identity Crisis, Alienation, Motherhood, Divorce, Death, Repressed Sexuality

\section{INTRODUCTION}

There are eleven stories intertwined together in Arranged Marriage. Each story is narrated by different narrators. These stories express about family relationship, young women's struggle in their newly married life, their expectation versus frustration, tradition versus modernity, loving versus abusive family bondage, marriage versus divorce, miscarriage versus abortion, different aspects of marriages, cultural conflicts, problem of adjustment etc. The women characters find a lot of struggle when they move from India to abroad or the western countries.

\section{THE BATS}

The story starts with seven-year unnamed character. She comes to realize that the narrator's mother is constantly

Revised Manuscript Received on December 24, 2019.

C.G.Karthikadevi Department of English, Part time Research Scholar in Kalasalingam University, Krishnankovil. Email: cgkarthikadevi@gmail.com.

Dr. R.Kannan, Associate Professor, Department of English, Kalasalingam Academy of Research and Education. Email: kannanraman1975@ gmail.com abused by her father. He is working Rashbihari printing press. Her mother used to cry when the child is sleeping. But the narrator pretends to sleep and watches the incident as a passive listener. Her father is a drunkard and regularly beats his wife. Her mother hides every scar and wound from her daughter. But the daughter tells that after a couple of days, her mother has another mark on her face. That wound is bigger and reddish blue.

Her mother decides to seek refuge to her uncle's home. She decides to go to Gopalpur to meet her uncle. The grandpa-uncle is a custodian to the orchards of a zamindar. One day a hoard of bats surround the mango grove. The bats keep on coming to the grove even though it is affected by poison. It symbolically means the marriage ties in India. The uncle says, "I guess they don't realize what's happening. They don't realize that by flying somewhere else they will be safe or maybe they do, but there's something that keeps pulling them back here." [8].

\section{CLOTHES}

The story depicts about the culture and tradition that has to be expected to follow by an Indian people who live in America. Sumita loves her husband sincerely and fulfils all his expectation. She has not forgotten to do her social obligations also. But all on a sudden, when she hears the death of her beloved husband her worldly life seems to be so dark. All her dreams shatter into pieces. She becomes helpless and destitute. The Indian women's miserable plight is expressed through the character of Sumita. "The sari, a thick voile that will bunch around the waist when worn, is borrowed. White.Widow's color, color of endings." [29]. She is not ready to live as a caged bird. She is also determined to begin a new life courageously and independently. "I straighten my shoulders and stand taller, take a deep breath. Air fills me-the same air that travelled through Somesh's lungs a little while ago. The thought is like an unexpected, intimate gift. I tilt my chin, readying myself for the arguments of the coming weeks, the remonstrations. In the mirror a woman holds my gaze, her eyes apprehensive yet steady. She wears a blouse and skirt the color of almonds" [33].

\section{SILVER PAVEMENTS, GOLDEN ROOFS}

The narrator Jayanti travels from Calcutta to Chicago. The story depicts about the desires and wishes and also the dreams of Jayanti to study in America. "As a child in India, sometimes I used to sing a song. Will I marry a prince from a far-off magic land, where the pavements are silver and the roofs all gold?" [44]. She also 
gets shocked on seeing the life of her aunt in America. She has understood that the life of an American is full of struggles.

\section{THE WORD LOVE}

The story starts with an unnamed character lives constantly in sin with an American man during her college life. She is quite opposite to the expectation of her mother. Her mother is very strict. Her mother expects to lead her daughter by having pleasing and good conduct with others. But she fails to do so. She lacks the reputation in the society. As a result she is roaming with an American man. She is ready to go to movies. Her mother disowns her for bringing shame to her family. Her relatives also deserted her. She feels depressed. She could remember the tale which is once told by her mother. The peasant allows her daughter to lead a life of her own. He never controls her. She leads an independent and easy goer life. He has given her full freedom to enjoy. As a result, she gets pregnant because of a promiscuous relationship and commits suicide. The peasant leaves the village with heavy hearted. Because of the daughter who brings shame to his family. In the same manner the narrator also plans to commit suicide. She starts to walk. She realizes her mistake. At the same time she decides to leave her mother and her boyfriend and starts to live a new life without any restrictions and judgement. "The word love, you see that you had never understood it before. It is like rain and when you lift your face to it, like rain it washes away inessentials, leaving you hollow, clean, ready to begin.” [71].

\section{A PERFECT LIFE}

Meera loves to lead an independent life. She has experienced all sorts of luxurious life in America. She does not want to bind herself in the chains of marriage. She is not ready to abide the rules of her husband. She loves to live a life of free bird. She loves her own individuality and privacy in her life. "Not that I was against marriage-or even against having a child." [74]. She has spent her precious time with the company of her boy friend Richard. "What I liked most about Richard was that he gave me space. I'd been afraid that after we slept together he'd either lose interest in me or start pressuring me to marry him. Or else I'd get pregnant. That was what always happened in India" [74].

\section{THE MAID SERVANT'S STORY}

In this story the wife comes to know that her husband exploit a maid servant sexually. The wife belongs to a rich class. Even though she does not leave her husband, she doesn't have that much courage to leave him and move her life independently. Because she is very concern towards her daughter's married life. She patiently endures all the pain. She does not reveal to anyone. "My first responsibility is the welfare of my family. That woman has caused nothing but trouble since the day she came" [154]. The status of his wife becomes non-payable prostitute. At the same time the status of maid servant becomes payable prostitute.

\section{THE DISAPPEARANCE}

The story is narrated by the husband's point of view. He is a traditional Indian male. He is also a very old fashioned man. But the wife doesn't love her husband. She feels abused in the name of arranged marriage. The husband forces her to have sex. It is like a 'legal rape'. She suffers the extreme level of pain. "But when she'd glanced up there had been a cool, considering look in her eyes. Almost disinterested almost as though she were wondering if he would make a suitable spouse" [171]. There is no love in between them. She is torn between the two cultures that is Calcutta and America.

\section{DOORS}

Preeti is a young woman who belongs to Indian origin. She is also brought up with American habits and customs. She accepts the life style of American people. Individual privacy is considered as an important one in this story. She gets married with Deepak. But he was fully brought up by Indian style and culture. According to Preeti's mother Indian men are not born with a set of prehistoric values. "It's never too late to stop yourself from ruining your life", her mother said "what do you really know about how Indian men think? About what they expect from their women?" [184]. The closed door of Preeti's room symbolize the individual freedom and privacy which violated by Deepak.

\section{THE ULTRASOUND}

Anju lives in the United States and Runu in India. They used to write letters to each other. Runu is less wealthy. She gets married with a traditional Brahmin family. Runu is also strictly controlled by her mother in law. Anju is a pregnant lady. She finds the test result that she has a boy and he is healthy too. But Runu is expecting a girl. Because her family decides that she must abort her child. Anju encourages her. But Anju's husband is angry and tells that she has to be obedient to her family. Anju remembers the ultrasound. She sees her son for the first time. She realizes that Runu must also going to have the same experience. The story ends with her planning to help Runu.

\section{AFFAIR}

The story is about a middle aged woman who named Abha. She gets married with Ashok. Abha is a prudent lady. She finds marriage is a trapping. She realizes there is no love, passion or sex. Her friend Mena falls in love with an American who is a co-worker. She plans to marry him after getting divorce. Abha leads an unhappy married life.

"I feel your resentment groaning around me, thick and red and suffocating. Like mine is suffocating you" [270]. She feels a discontent life in living with Ashok. Abha writes a letter to her husband. Ashok explains all the reason. She starts to lead a life of her own by leaving her husband and live independently. 


\section{MEETING MRINAL}

In this story Asha is the protagonist. She has immigrated to the United States through the traditional marriage. She is torn between the two cultures. She leads the life perfectly as an Indian woman. But her husband leaves her by running after a white woman. Asha feels disappointed. She meets Mrinal who is her childhood friend from India. Later on Mrinal becomes a successful woman. After their meeting Asha plans to commit suicide. Thousand thoughts come to her mind. Asha comes to realize that suicide is not the answer. Her son Dinesh takes her to home. She notices that life is not about being perfect but it has beauty in its imperfections. She plans to write a letter to Mrinal describing about her imperfect life.

\section{CONCLUSION}

All the young women characters suffer a lot of pain in their life. Mostly they suffer because of immigration to the United States. They have cultural conflicts in their life between the lands they born and the land they settle. There is a lot of difference between one who brought up by Indian culture and one who nourished upon American culture when they seek job opportunity, learning education and family settlement in the United States.

\section{REFERENCE}

1. Divakaruni, Chitra Banerjee, Arranged Marriage. London: Black swan edition, 1997.

\section{AUTHORS PROFILE}

C.G. Karthikadevi, Research Scholar, Department of English, Kalasalingam Academy of Research and Education.
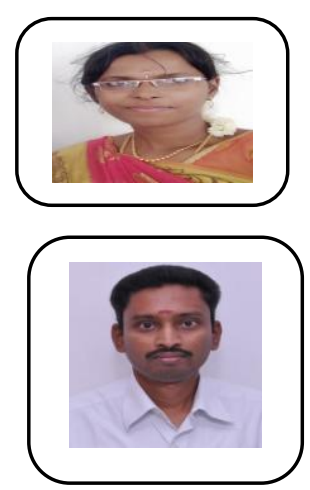

Dr.R.Kannan is an Associate Professor of English in Kalasalingam Academy of Research and Education. He completed his Ph.D. in 2009. He has a teaching experience of over fourteen years. Under his guidance, one awarded his Doctorate, fourteen scholars completed their M.Phil dissertation. At present, under his supervision, four scholars are pursuing their Ph.D. He has published two papers in Scopus Indexed Journal, fourteen papers in UGC listed and other journals and also presented papers in both National and International conferences. He was a Doctoral Committee Member in VIT, Vellore. $\mathrm{He}$ is the journal reviewer of Humanities, Online International Journal, Switzerland. He is the BEC Centre Exams Manager and Speaking Examiner for BEC in Kalasalingam Academy of Research and Education. 